\title{
Open Source Software in Slovenian Primary and Secondary Schools
}

\author{
Mojca TOMAZIN \\ Business School in Brezice \\ Bizeljska cesta 45, 8250 Brezice, Slovenia \\ e-mail: mojca.tomazin2@guest.arnes.si \\ Miro GRADISAR \\ Faculty of Economics \\ Kardeljeva ploscad 17, 1000 Ljubljana, Slovenia \\ e-mail:miro.gradisar@ef.uni-lj.si
}

Received: August 2006

\begin{abstract}
This article deals with the use of Open Source Software (OSS) at the primary and secondary level of education in Slovenia. The challenges and advantages of using OSS in educational processes are discussed. The main advantages of OSS are: economic freedom, stability, reliability and a possibility of making modifications but - on the other hand - the main problem for schools can be installation and support. The research carried out to determine the use of OSS in schools is described and the results are compared with the results of similar research studies in Germany, Sweden and UK. The results of both surveys show, that Linux and OpenOffice.org are the most popular OSS applications on computer desktops. The most important conclusion (according to our research) is that lack of knowledge prevents a faster introduction of OSS in education.
\end{abstract}

Key words: open source software, learning technology, primary education, secondary education.

\section{Introduction}

While the use of Information and Communication Technology (ICT) is becoming more and more important in the learning environments, this technology is usually very expensive. This causes the global digital divide between the information-rich and informationdeprived worlds, which affects educational opportunity (Tiene, 2002; Kirkwood, 2001). Longitudinal studies can provide individual histories of educational attainment of children and their results show that the main source of variation in achievement is due to differences in social background (McNiece et al., 2004). Internet with open solutions and Open Source Software (OSS) could be really helpful in reducing these differences. Therefore, we presume that educational systems around the world should take into consideration not only Closed Source Software (CSS) but Open Source Software as well. This has been confirmed also by the 'Open Source Software in Schools' study (Becta, 2005), published in May 2005 by the British Educational Communications and Technology Agency (Becta). According to their definition OSS is, "Non-proprietary software 
for which the underlying programming code is provided and may be modified to more closely fit users' needs. It is usually very low cost or free and does not incur the payment of licensing fees". The findings of Becta's study show that OSS can provide a suitable technical infrastructure and a basic set of applications for classroom use and that it can offer a cost-effective alternative to CSS. It is interesting that the same agency (Becta) has been lately accused of inconsistency in its strategy towards open source, following the discovery that it has omitted many open source products from the educational software databases (Marson, 2006a).

A major threat for the OSS development is software patenting. However, in May 2006 it was published that the European Commission's stance is that computer programs will be excluded from patentability in the upcoming Community Patent legislation, and that the European Patent Office will be bound by this law (Marson, 2006b).

With the rising popularity of OSS many authors started to write about various benefits and disadvantages of OSS (Payne, 2002).

Despite all advantages, the introduction of OSS in schools is progressing very slowly. Surprisingly, not many studies have addressed this problem. According to our knowledge only two other studies have been published besides the Becta's until now. One of the studies was conducted by the Northwest Regional Educational Laboratory (NREL) in the USA (NREL, 2002). The purpose of it was to study the use of OSS in K-12 educational system. The other study, entitled 'Free/Libre Open Source Software (FLOSS): Evidence from Germany, Sweden and UK' (FLOSS, 2002), is the most extensive study made in Europe in this field. As such, FLOSS presents a systematic research of OSS in companies and public institutions and is not limited to educational systems only.

Probably the results of FLOSS and other researches cannot be directly adapted to all other countries and different institutions. Therefore, we decided to conduct a similar research as FLOSS but focused on the introduction of OSS in Slovenian schools, where the current situation is that the ICT infrastructure is based mostly upon Microsoft software. Slovenia is small, yet it is the most developed country of those that joined the EU in 2004.

In the remainder of the paper the methodology of the research is described first and then the results are presented and compared with those of similar research studies in Germany, Sweden and UK. At the end, the main findings are summarized and implications and suggestions for further research are given.

\section{Some Facts about OSS}

\section{Advantages and Disadvantages of OSS}

The crucial economic freedom provided by OSS is the prospect of elimination of the licensing costs (Browne, 2001). What should be done if the goal is to teach the students how to work with a UNIX-like operating system? Unfortunately, schools are typically under-funded, which means that they are unable to buy commercial UNIX-systems. A solution for this dilemma is the usage of OSS such as Linux (Höpfner, 2003). 
Another benefit is the stability and reliability. Since anyone can see the source code, bugs can be repaired quickly. In addition, with the source code being available for all to see, greater security is provided as deficiencies in the software are readily found and fixed at an amazing rate (Hart, 2004).

A possibility of making practically unlimited modifications and customizations is also an important advantage of OSS. Some users in education try to customize CSS, for example Microsoft Office (Deacon et al., 2004), but these are only customizations 'on the surface' and have other limitations regarding the redistribution of their 'added value'.

One important idea in education is also to teach computing concepts (Hart, 2004). For example, OSS OpenOffice.org offers word processing very similar to CSS products, usually MS Office. Teaching word processing as a concept by using different software can provide students with a greater breadth of information.

Proponents of OSS claim that OSS is more powerful than other solutions within the world of the Internet and advanced technology (Chasell, 2000).

We can also find some specific obstacles in the education field. For example, even if the main policy framing ICT in education includes the provision of hardware and infrastructure as its main target, little advice on how they might be used is offered (Dale et al., 2004). Opportunities for appropriate training are usually limited, with many educators being self-taught IT users (Carmichael and Honour, 2002).

An additional problem for schools can be installation and support, especially regarding OSS (Butcher, 2002). Teachers, who are experts in their subject area and masters of their craft, can find themselves in an uncomfortable position having to relearn how to teach in a new environment with little or no support (Ellis and Hafner, 2003).

All secondary schools in Mongolia use non-license Microsoft Windows operating system and non-license Microsoft Office package although there were a number of initiatives to introduce open source Linux operating system. However, most of them failed due to inadequate graphic user interface and uncommon use for home and office (Uyanga, 2006).

\section{Different Types of OSS}

In this paper we discuss four different areas of OSS use: as a server operating system, as a database, for desktops/clients and for developing and maintaining web pages.

Desktop OSS offers several versions. OSS can serve either as a desktop operating system or as a client-side operating system (i.e., Linux). It can also present software, which is usually part of the operating system, but was developed by third-party developers (not same as operating-system-core developers). Such examples are KDE and Gnome desktop environments, which are the most commonly used environments in combination with Linux operating system. Besides the already mentioned options, desktop OSS also includes other applications, such as browsers, office suites etc.

\section{Research Methodology}

A survey based on a web questionnaire was selected as the most appropriate method of data collection for the study. We decided to use a similar questionnaire as used in 
FLOSS. The questionnaire was developed based on the results of numerous previous interviews with company/institution presidents who already use OSS. Before its final version, the questionnaire was tested several times. Interestingly, FLOSS survey was also used as a model for another study (besides ours) conducted by the Stanford Institute for Economic Policy Research SIEPR, entitled 'FLOSS-US: The Free/Libre/Open Source Software Survey for 2003' (FLOSS-US, 2003).

Invitations to take part in our survey along with the username and password were sent in January 2004 through mailing lists to the principals of 151 secondary schools, 463 primary schools, 41 primary schools for children with special needs, and 81 music schools. The principals were asked to find a competent person to give answers for their school. The data were collected by March 2004. 430 entries were submitted but only 140 (33\%) were valid. All incomplete questionnaires were excluded from the analysis. Nevertheless, valid questionnaires represent $19 \%$ of the target population. Most of the participants (65\%) in the research were ICT teachers.

\section{Results}

Research results have been grouped according to the following 3 categories:

- OSS in different areas of use;

- important influences on the decision to use OSS;

- motives, obstacles and suggestions for using OSS.

\section{OSS in Different Areas of Use}

The participants were supposed to select the type of software they use in each of areas, mentioned in the second chapter. Their options were the following: we use it, we plan to use it (in a year's time), we do not use nor plan to use it, and I don't know.

Regarding OSS as a server operating system the most popular of Linux distributions has proved to be Linux Red Hat with $24 \%$ of the participants using it or planning to use it. Pingo Linux (which was not pre-entered so the participants had to enter it themselves) is also quite known $-8 \%$ of participants said they use or plan to use it. 'Pingo Linux' is a modified Slovenian system based on Red Hat. It is localized and includes all necessary applications for basic and advanced use.

In database section, two options - MySQL and PostgreSQL - were predefined, with a possibility of entering other options. MySQL is being used by 3\% of the participants, while further $14 \%$ plan to start using it in a year's time. PostgreSQL is not a popular solution amongst most of the participants since only $5 \%$ of them use or plan to use it. Among 'other' options only Cobol was mentioned.

The most frequently used desktop OSS is OpenOffice.org office suite, which is already being used by nearly one third of the participants, while another $31 \%$ plan to use it. A very similar ratio is for Mozilla browser. Predefined options were also Linux, KDE and GNOME but less than $10 \%$ of the participants use or plan to use them. 
In 'OSS for developing and maintaining web pages' section the predefined options were: Apache, PHP, Perl and JSP. As usual, participants could also add some other options on their own. PHP is used by only 5\% of the participants, and the percentage of other options is even lower. Amongst 'other' options one participant mentioned OpenOffice.org and the other Mozilla-Composer, both for developing web pages.

\section{Important Influences on the Decision to Use OSS}

In this section we were interested in the importance of certain pre-defined criteria in the decision to use OSS. Naturally, the information on direct financial advantages of using OSS would be very beneficial. This goal, however, was found to be unrealistic and was dropped during questionnaire testing in FLOSS survey. Companies, interviewed in this phase, were generally unable to provide even approximate estimates on financial benefits of using OSS. That is why the researchers focused more on the question of how important the criteria from the list were for their decision to replace CSS with OSS. While it was impossible to transform the responses to this question into financial terms, it does however illustrate the importance of individual OSS characteristics for this decision.

A complete list of criteria from the original FLOSS study consists of 14 items. The list was generated on the basis of a wide specter of literature sources on using OSS and its potential advantages. They had also taken into consideration the total cost of ownership (TCO) concept, which includes not only direct licensing fee costs but also the cost of users' education, support, and integration of the new solution into an existing IT infrastructure etc. Taking all these financial aspects into consideration, we soon come to a conclusion that lower licensing-fee software can suddenly become expensive, and vice versa.

Our research did not go into so many details and had used only 6 of the 'original' 14 criteria - the ones that were simplest to be understood and evaluated by our intended audience. Following is a list of these 6 criteria: open source and/or possibility to change it, lower cost/free, higher stability, protection from unauthorized access (security), better functionality, and hardware savings. The participants were asked to grade only the software they are already using. The importance was graded with the following options: very important, important, quite important, not important and I don't know.

The most important factors in selecting Linux as server operating system has proved to be its stability ( $82 \%$ very important/important) and security ( $76 \%$ very important/important), followed by its price and functionality. The open source philosophy and savings in hardware were less important. A Unix like operating system Free/Open BSD and MySQL both received very little answers in total. The 'Linux on desktops' category shows the importance of price (58\% very important/important). Also important features are security and stability. Very important factors in selecting KDE as desktop environment are its stability (80\% very important/important), price and security (73\% very important/important for both). The 'Gnome desktop' category has also received very few answers. The most important factor in selecting Mozilla turned out to be price ( $78 \%$ very important/important), followed by security ( $70 \%$ very important/important). 
An obvious factor in using the OpenOffice.org office suite is its price $(69 \%$ very important/important), which is, interestingly, followed by its open-source philosophy (53\% very important/important). Apache web server users rely on its stability and functionality (71\% very important/important for both). The most important factor in using PHP is functionality (65\% very important/important). Price plays an important role in selecting Perl (71\% very important/important).

\section{Motives, Obstacles and Suggestions for Using OSS}

All participants were asked to select the level of agreement or disagreement (I agree, I partially agree, I do not agree, and I don't know) with pre-defined statements about using OSS, motives for using it, and obstacles connected with using it. At the end of the section there was an open question, where the participants could suggest a better way of implementing OSS in schools.

The main motive for using OSS in education is the desire of educational establishments to become more independent of the policies and licenses of certain software producers. $60 \%$ of the participants agree with this statement (Fig. 1). Interestingly, this is very similar to the results of the recent informal survey of visitors to the Computer Economics website (Computer Economics, 2005). Their survey indicates that in using OSS 'reduced dependence on software vendors' is even more important to buyers than low cost. Fig. 1 also shows us what the participants think about two other statements.

Only $13 \%$ of the participants agree with the claim that OSS is not needed in the teaching processes because the existing CSS fulfills all their needs. Over a third of the participants agree that teachers and other employees in educational establishments (schools) wish to use it but lack the knowledge (Fig. 2).

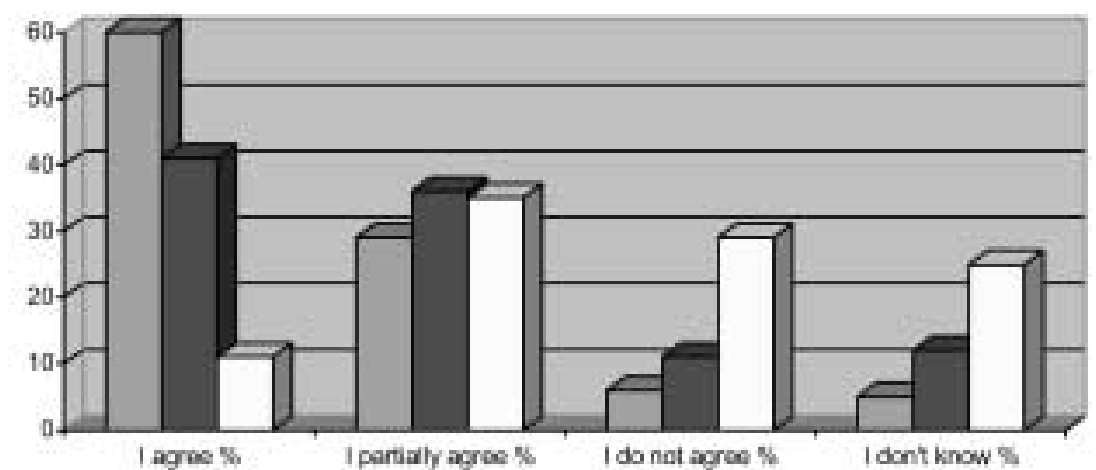

口We use OSS becasse wo wish to bocome more holependent of the loersing and peicing polcies of the prevaling softesare developers.

Ely using OSS we wish to support the efforts of openscurce community.

DWe prefer using OSS - thet is our schools poicy.

Fig. 1. The level of agreement with pre-defined statements about using OSS. 


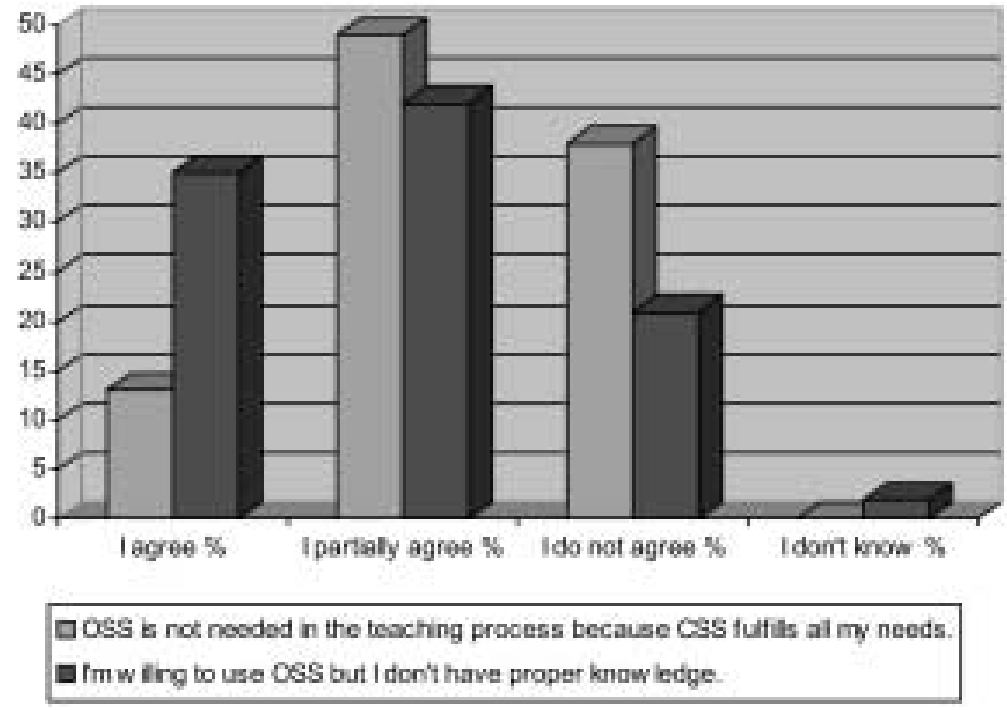

Fig. 2. The opinion of participants on using OSS in teaching process.

The percentage of the participants who do not see the need for OSS in school administration tasks is higher $(21 \%)$. On the other hand, over a third of them say that they are willing to use it but do not have the proper knowledge.

The answers to the question, "Which are, in your opinion, the main obstacles preventing the use of OSS in education?" are fairly equally divided among predefined options. But the highest percentage of participants agree that teachers and school administrators have not been trained well enough to use OSS and are thus unable to use it (81\%). This opinion is also supported by the answers to the next question, "Can you suggest a better way to start implementing OSS in schools?" More than a half of the participants answered this open-type question. It turned out that the participants had many suggestions, which we were able to group into different categories. Their ideas showed that the solution to using OSS in schools is in educating its future users.

\section{Comparison between the Results of Our Survey and Those of FLOSS}

While research results have been compared in all categories, we will describe only the most interesting similarities and differences. Despite a slightly different methodology used in the FLOSS research (made in Germany, Sweden and UK), the operating system Linux seems to be the most widespread operating system for servers. After comparing the results of both surveys in regard to operating systems, we can conclude that the order of the first three most important selection criteria, which are: higher stability (first place), higher security (second place), and lower cost (third place), is identical in both cases, where even the percentages match very closely. Interestingly, the main characteristics of OSS - free access to source code and permission to modify it - are not one of the main 
factors in the decision for choosing the OSS operating system according to both surveys. The same applies to hardware savings.

The results of both surveys are slightly different in case of database software. In FLOSS, the most important factor is its stability followed by security and price. Our research, however, shows lower cost as the most important criterion, with stability and functionality coming in at second and third places.

According to the FLOSS study, Linux takes the first place in desktop OSS use, followed by an office suite and a desktop environment (KDE). Our research shows OpenOffice.org office suite as the most popular OSS desktop application, followed by Mozilla browser and the Linux operating system. While the FLOSS survey again delivers the standard stability-cost-safety threesome, our survey showed the same relationship only for Linux desktops. In case of the Mozilla browser and OpenOffice.org office suite, users seem to prefer their price (they are available free) before safety and stability. Interestingly, an important factor in this area is also its open source.

The results of the FLOSS survey show that Apache web server is the most popular web software, while our survey participants prefer PHP web programming language. The FLOSS results show stability, security and lower cost as the most important selection criteria for web software, while our survey shows a different situation. The most important characteristic of web software is simply its better functionality.

In FLOSS study it stands, that the decision to use OSS is generally influenced by two types of motivation. The first group is linked to a specific application, which is expected to contribute to greater stability or lower cost when compared to commercial alternatives. The other type of motives is more general, i.e., to support open source community. Below are the comparisons of the results with regard to three different statements:

'We use or plan to use OSS because we wish to become more independent of the policies of big software companies.'

One argument for using OSS is to become less dependent on the pricing and licensing policies of the large software-developing companies. In public sector, this argument represents the most important motive for using OSS. Their tight budgets, unsupported old software versions and constant changing of licensing schemes leading to even greater costs will soon make them aware of the advantages of independence from big software companies.

In the FLOSS survey, $30 \%$ of the participants totally agree with this statement and $19 \%$ totally disagree. In our survey, as much as $60 \%$ agree with it, while only $6 \%$ disagree.

'By using OSS, we wish to support open-source community.'

In the FLOSS survey, $14 \%$ of survey takers completely agree with the statement and $29 \%$ disagree. In our survey, $41 \%$ of those taking the survey agree and $11 \%$ disagree with it.

'We prefer using OSS - that is our company's policy.'

Companies and institutions can develop their internal policies regarding which software to use. Such policies help maintain the homogeneous IT infrastructure and decrease cost. They can also be motivated by strategic reasons, such as to save money by eliminating the cost of licensing fees, for security reasons or to be able to adjust source code. 
In the results of the FLOSS survey, $8 \%$ said a definitive yes to the statement, while $48 \%$ said no. In our survey, $11 \%$ agree and $29 \%$ disagree with having this sort of software policy.

\section{Summary and Implications for Further Research}

Let's summarize the most important findings of our research:

- The most popular of Linux distributions regarding OSS as server operating system has proved to be Linux Red Hat.

- Use of OSS for databases is very limited.

- The most popular OSS on desktops and clients is OpenOffice.org office suite. Quite popular is also Mozilla browser.

- The three most important OSS characteristics that influence the decision to use it are price, security and stability.

- The main motive for using OSS in education seems to be the desire of educational establishments to become more independent of the policies and licenses of certain software producers.

- Over one third of the participants agree that teachers and other employees in schools wish to use OSS but lack the knowledge. Therefore, the solution to using OSS in schools is in educating its future users.

The most interesting findings in comparison between OS project and FLOSS research are:

- Operating system Linux is in both cases the most widespread OSS operating system for servers.

- In both surveys the most important characteristics of OSS for servers are stability, security and price.

- If we combine the results of both surveys we can conclude that Linux and OpenOffice.org are the most popular OSS applications used or planned to be used on computer desktops.

- The Slovenian participants find it more important to be independent of the policies of big software companies. 30 percentage points more of them agree with this than in the FLOSS survey.

- 27 percentage points more participants wish to support open source community by using OSS in Slovenia than in the FLOSS survey.

The most important conclusion that we can draw from our research is that lack of knowledge prevents a faster introduction and implemantation of OSS in education. Therefore, we will focus our future research on cost effective ways and methods (for ex. training, documentation, web resources...) of providing more knowledge about OSS to all potential users.

Comparison between the results of our survey and FLOSS shows some interesting variations that are country-specific. Therefore, we suggest that every country planning to introduce OSS into schools and other institutions should make a similar research. 
We would also like to mention that the OS philosophy is not only about software. There are many initiatives to make open to the public all kinds of learning resources as e-resources. Wikipedia might be the most famous example of this kind. Furthermore, in modern educational institutions we can successfully use Open Source Learning Management Systems (LMS) instead of commercial LMS to handle learning and teaching processes (Grob, 2004).

Finally, we have taken the first steps to start an international project on research of OSS use in primary and secondary schools by posting an invitation to schools throughout Europe at eTwinning portal (eTwinning, 2007). 'eTwinning' is the main activity of the European Union's eLearning programme, which promotes the use of ICT at schools in Europe. Teachers and students use the Internet to cross borders - they cooperate, exchange information and share learning materials. We hope that a lot of schools from different countries will join our project in the efforts to continue the research in this interesting field.

\section{Acknowledgement}

This research was supported by Ministry of Higher Education, Science and Technology of the Republic of Slovenia under the grant No. P2-0037.

\section{References}

Becta - British Educational Communications and Technology Agency (2005). Open Source Software in Schools - A Case Study Report.

http: //publications.becta.org.uk/display.cfm?resID=25908 (accessed September 1, 2007).

Bonaccorsi, A., and C. Rossi (2003). Why Open Source Software Can Succeed.

http: //opensource.mit.edu/papers/rp-bonaccorsirossi.pdf (accessed September 1, 2007).

Browne, C. (2001). The Economics of Free Software.

http: / / cbbrowne.com/info/freeecon.html (September 1, 2007).

Butcher, M. (2002). Linux in education: Open Source provides a better solution to schools. Newsforge - The Online Newspaper of Record for Linux and Open Source.

http: / / newsforge. com/article.pl?sid=02/05/17/1319208\&mode=thread\&tid=46 (accessed September 1, 2007).

Carmichael, P., and L. Honour (2002). Open source as appropriate technology for global education. International Journal of Educational Development, 22(1), 47-53.

Chassell, J.R. (2000). Free Software - Access and Empowerment.

http://www.cis.strath.ac.uk/research/seminars/0202_chassell.html (accessed September 1, 2007).

Computer Economics (2005). The Key Advantage of Open Source. http://www.computereconomics.com/article.cfm?id=1043 (accessed September 1, 2007).

Dale, R., S. Robertson and T. Shortis (2004). 'You can't not go with the technological flow, can you?' Constructing 'ICT' and 'teaching and learning'. Journal of Computer Assisted Learning, 20(6), 456-470.

Deacon, A., J. Jaftha and D. Horowitz (2004). Customising Microsoft Office to develop a tutorial learning environment. British Journal of Educational Technology, 35(2), 223-234.

Ellis, J.T., and W. Hafner (2003). Engineering an online course: applying the 'secrets' of computer programming to course development. British Journal of Educational Technology, 34(5), 639-650.

eTwinning. http: / / www . etwinning . net (accessed September 1, 2007). 
FLOSS - Free/Libre Open Source Software (2002). Use of open Source Software in Firms and Public Institutions, Evidence from Germany, Sweden and UK.

http: / / www. infonomics.nl / FLOSS / report / (accessed September 1, 2007).

FLOSS-US (2003). The Free/Libre/Open Source Software Survey for 2003

http: / / www. stanford. edu/group/floss-us (accessed September 1, 2007).

Grob, H.L. (2004). Developing, deploying, using and evaluating an open source learning management system. Journal of Computing and Information Technology - CIT, 12(2), 127-134.

Hart, T. (2004). Open Source in Education.

http://portfolio.umaine.edu/ hartt/osined/osined-1.0.pdf (accessed September 1, 2007).

Höpfner, H. (2003). Open Source Software in education: a report of experience. Informatics in Education, 2(1), 15-20.

Kirkwood, A. (2001). Shanty Towns around the Global Village? Reducing distance, but widening gaps with ICT. Education, Communication \& Information, 1(2), 213-228.

Marson, I. (2006a). Becta fails the open source test.

http://news. zdnet.co.uk/software/applications/0, 39020384, 39256053,00.htm (accessed September 1, 2007).

Marson, I. (2006b). Europe: No patents for software.

http: //news.com.com/Europe+No+patents+for+software/2100-1014_3-

6076418.html (accessed September 1, 2007).

McNiece, R., P. Bidgood and P. Soan (2004). An investigation into using national longitudinal studies to examine trends in educational attainment and development. Educational Research, 46, 119-136.

NREL (2002). Northwest Educational Technology Consortium: Making Decision About Open Source Software (OSS) for K-12.

http: / / www . netc.org/openoptions / (accessed September 1, 2007)

Payne, C. (2002). On the security of open source software. Information Systems Journal, 12(1), 61-78.

Tiene, D. (2002). Addressing the global digital divide and its impact on educational opportunity. Educational Media International, 39(3-4), 212-222.

Uyanga, S. (2006). The current situation of informatics education in Mongolia. Informatics in Education, 5(1), $133-146$.

M. Tomazin graduated from University of Ljubljana, Slovenia, in 1988 with BSc in electrical engineering. She received a MSc in informatics science from University of Ljubjana in 2003. She teaches courses in Business Informatics at the Business School in Brezice, Slovenia. Areas of research interest include use of free/open source software and e-resources in education. She also works in various work groups of the Ministry of Education in Slovenia. Together with her students she often takes part in various international projects.

M. Gradisar, $\mathrm{PhD}$ is a full professor of informatics and computer systems at the University of Ljubljana and at the University of Maribor. His major research interests are in information systems (insurance, healthcare, education), human-computer interactions, decision analysis, and optimization techniques. He was a visiting professor at the University of Baltimore and University of Bremen. 


\section{Atviroji programinė ịranga Slovėnijos bendrojo lavinimo mokyklose}

\section{Mojca TOMAZIN, Miro GRADISAR}

Šiame straipsnyje aptariama atviroji programinè ịranga Slovėnijos bendrojo lavinimo mokyklose (pagrindiniame ir viduriniame lygmenyse). Nagrinèjami atviruju programu trūkumai ir pranašumai Pagrindiniai pranašumai yra nemokamas arba beveik nemokamas naudojimas, pastovumas, patikimumas, lankstumas - galimybė nesunkiai modifikuoti, tačiau mokykloms reikia paramos jas diegiant ir prižiūrint. Straipsnyje pateikiamas tyrimas apie atvirosios programinès ịrangos naudojimą mokyklose. Gauti duomenys buvo lyginami su tų analogiškų tyrimų duomenimis, atliktais Vokietijoje, Švedijoje ir Jungtinejje Karalysteje. Šie tyrimai parodè, kad populiariausia atviroji programinè ịranga yra "Linux" ir "OpenOffice.org”. Svarbiausia tyrimo išvada: žinių trūkumas trukdo sparčiam atvirosios programinès ịrangos ịvedimui ị mokymą. 